\title{
THE EFFECTIVENESS OF USING NATURAL APPROACH TO IMPROVE STUDENTS' INTERACTION ABILITY AT THE SECOND GRADE OF SMAN 4 PINRANG
}

\author{
DesyLestary ${ }^{1}$, Anwar Sani ${ }^{2}$ \\ InstitutAgama Islam Negara (IAIN) Parepare \\ desylestary389@gmail.com ${ }^{1}$
}

\begin{abstract}
This research aimed to know-how is the effectiveness of using Natural Approach to improve students' interaction ability. Students should have an ability to build interaction in order to actualize the function of language as device communication which occurs within classroom activity and create an interactive teaching and learning process so it must be considered to be improved. This study employed a collaborative classroom action research design where the writer and collaborator work together in conducting this study. The subject of this research was the 25 students of XI IPA 1 at SMAN 4 Pinrang in the academic year 2018-2019. This study was carried out in two cycles which conducted in three meetings for each cycle by taking classroom action research phases i.e. planning, action, observation, and reflection. This study was descriptive qualitative research which used observation checklist, interview, and questionnaire as instruments of collecting data. The result after analyzing data qualitatively showed that (1) by using Natural Approach, students could participate in performing instructions and conveying responses during teaching and learning process. (2) They were active in giving feedback, answering questions, moreover, doing interaction within classroom activity. (3) Every class activity of each Comprehension (Pre-production), Early Production, and Speech Emergence stages in the two cycles encouraged them to involve actively in the teaching and learning process. Those descriptions indicate the effectiveness of using Natural Approach to improve students' interaction ability.
\end{abstract}

Keywords: Natural Approach, interaction ability, classroom action research.

\section{Introduction}

Language is a purely human and non-instinctive method of communicating ideas, emotions, and desires by means of a system of voluntarily produced symbols (Edward Sapir, 1949). People as social beings are in need of language to create interaction from one to another in their daily lives. In other words, interaction among people can be carried out by using language as a device of communication. They formulate their utterances with the goal of having their intentions recognized by the interlocutors (KaharuddinBahar, 2014). 
Humans interact with other people in order to express their ideas, feelings, thoughts, as well as their wishes to others. Interaction is commonly found in our real social lives in terms of interpersonal dialogues or conversations.

Nowadays English is an important language. It is the key to international currencies of technology, science, as well as commerce. Moreover, this era is known as a megacompetition, in which competitors have to possess the pre-requirement of being able to use English as communication means. As an international language, English has gained its popularity all over the world including Indonesia. Therefore, learning English becomes an important thing to master. They need to look charming when producing English well so that they can use it to interact with other people or foreigners confidently. They will get this ability by learning English in formal, informal, or non-formal education. Yet, in Indonesia, formal education in school is still become the main equipment to learn English.

In learning English, students are obligated to use English in building interaction with other people in order to actualize a function of language as a device communication. It becomes a problem when students are given theories about English and even as they want to interact with other people, yet they cannot produce any word in English to do it. Moreover, students cannot produce English even in the teaching and learning process. When teachers ask their students to speak up or asking a question about English material that has been taught, some of them just keep quiet. It can be caused by students and teachers side such as lack of students' knowledge about English, confidence, abashment to produce the language, or teaching monotonously by English teachers which cannot stimulate them. It is one of the obstacles for the eager desire to create an effective and efficient learning process. A solution for solving the problems is doing practice, where students must be accustomed to interacting with their friends, teachers and other people.

Natural Approach will help students to learn how to produce English communicatively when they interact with other people (especially in the classroom). Furthermore, this approach stimulates students and teacher to interact with one another actively. When the teacher gives them some instructions or activities to create any interaction with their friends or teacher and as well students will be encouraged to involve 
their mind and gesture actively to do it. It will aim them to familiarize with classroom interaction to avoid a passive learning process.

At SMAN 4 Pinrang, the researcher found that the teaching and learning process is still monotonous. We can say that the English teacher uses a conventional way to teach English so that some students cannot be involved actively in the learning process. This conventional way refers to a teaching method which involving teacher and students interacting face-to-face manner in the classroom. The teacher is explaining and writing on the board, students will be copying the same thing onto their notes, some of the students are dreaming away and some are sleeping. It would be difficult to stop students from copying the notes from the board and at the same time ensured that every student was paying attention in the class while their teacher was too busy explaining the material. Then, some exercises in the textbooks will be given until the class end. This manner is also limiting the room for more creative thinking which does not give any progress in students' language acquisition and also seldom considering individual differences in comprehending the material.

It is necessary to realize these limitations in conventional teaching which the teachers initiate discussion in the classroom, and exclusively focuses on knowing the content in the textbook and notes. Students receive the material passively by taking notes and reiterate the material after the explanation from their teacher. Then, they will memorize it in the exams. Hence, they have no much chance to communicate the language that they learned. The objective of English learning in speaking aspect, however, students are provided to communicate the language both written and oral. Communicating a language to interact with one another with fellow or teacher is one way to encourage the students' language acquisition in the teaching and learning process.

So, as the researcher believes that Natural Approach is able to overcome the problems. Considering the phenomenon above, the researcher decides to carry out the research entitled "The Effectiveness of Using Natural Approach to Improve Students' Interaction Ability at the Second Grade of SMAN 4 Pinrang".

Based on the statement above about the background of this research, the problem statements can be formulated as follow; "How is the effectiveness of Natural Approach to 
students' interaction ability at the Second Grade of SMAN 4 Pinrang?" and "How is the improvement of students' interaction ability by using Natural Approach at the Second Grade of SMAN 4 Pinrang?" Furthermore, related to the problem statements, the objective of the research finds out the effectiveness of Natural Approach to students' interaction ability at the Second Grade of SMAN 4 Pinrang and the improvement of students' interaction ability by using Natural Approach at the Second Grade of SMAN 4 Pinrang.

There are two significances of this study, firstly theoretical significance which this study provides a beneficial and referential contribution in giving information or knowledge as the way to improve students' interaction ability by using Natural Approach. Next, the second significance is aim to the researcher, students, teacher and other researchers who conduct similar research which called practical significance. For the researcher, the researcher will get experience and knowledge in English teaching especially how to create an interactive teaching and learning process. Then, for the students, students will get a better learning system and get a meaningful experience so they will use English to interact with their friends and teacher, in order to involve actively for using English in their daily

lives. Next, for teachers, teachers can improve their professionalism to make any innovation and choose alternative techniques to achieve an effective teaching and learning process. And, for other researchers, the findings of the research can be used as one of the references in conducting research on English language teaching, especially the effectiveness of Natural Approach to improve students' interaction ability.

\section{Research Method}

This study was conducted at SMAN 4 Pinrang on July-Augusts which include six meetings. The participants of this study were 25 students of XI IPA 1 in the academic year 2018-2019. This study applied a collaborative classroom action research design which carried out in two cycles which conducted in three meetings for each cycle by taking classroom action research phases i.e. planning, action, observation, and reflection.

This study was a descriptive qualitative approach in order to describe, investigate, and explore the real situation that happens during the research which used observation 
checklist, interview, and questionnaire as instruments of collecting data. Furthermore, the data were analyzed by three activities according to Miles and Huberman. The first activity was data reduction that is selecting, simplifying, and transforming the "raw data" from the research field (Yaumi\&Damopolii, 2014). This appeared from field notes and managed into an orderly pattern.

After the reduction process, the next activity was the data display. Data display is data collection in narrative form which has been arranged and abstracted so easier to understand. Data display is conducted in order to organize data which is a systematic compilation of information from the results of data reduction starting from planning, action, observation, and reflection of each cycle. Those activities were done in stages, after that, the researcher and collaborator drew the conclusion of the analyzing process.

\section{Finding and Discussion}

This part explained the findings and discussion of the study. It was about the data description of each cycle by taking classroom action research phases; planning, action, observation, and reflection.

\section{A. Findings}

The first cycle (cycle 1) began by a discussion with the English teacher of XI IPA 1. It discussed the English teaching schedule and the teaching and learning rules of the lesson. The researcher and collaborator teacher talked about the situation and condition of the students, then, settled the planning that had been prepared. The researcher was given the opportunity to get acquainted with students before conducting the first meeting of the research.

The description of the research in cycle 1 was presented in this part which consisted of planning, action, observation, and reflection phase of cycle 1. It was also included the result of the observation checklist and interview. The first phase of this cycle is planning where the researcher made planning for the action based on the problems faced by students. Firstly, the researcher arranged a lesson plan based on the teaching material. Then, the researcher also prepared an observation checklist to observe students' activities during the teaching and learning process and interview guide to know students' responses. Those 
techniques were used to identify the effectiveness of using Natural Approach to improve students' interaction ability.

The next phase was the action which had been conducted on July $24^{\text {th }}, 30^{\text {th }}$, and $31^{\text {st }}$ 2018. In this phase, the researcher implemented the lesson plan that has been made before related to the using of Natural Approach in the classroom as well. In the teaching process, the researcher used three activity phases, those are opening, main process, and closing.

The third phase of this cycle is observation which consisted of the result of the observation checklist part A and part B, and interview which analyzed before the researcher conducted the reflection.

\section{Observation Checklists}

Students' activity during the action was observed by the researcher and collaborator. Observation checklist divided into two sheets, observation checklist part A and part B. Both of them were made to describe all activities of students during the teaching and learning process by using the Natural Approach. However, part A showed about general students' activity that must be observed, meanwhile, part B showed students' activity individually.

First, it was related to the observation checklist part A which all aspects had been a checklist, but the checklists frequency still not fulfill for the whole meetings. In this cycle, the observation checklist for the three meetings showed that only the activity 1 and 3 had been fulfilled for each meeting which the researcher and students began the class by conducting opening activities and most of the students paid attention during the teaching and learning process.

In this cycle, students did not look quite an enthusiast because they still felt awkward about the situation in the classroom after long semester break for a new academic year, and it gave effect to their motivation to learn. Students were still passive in asking and answering a question or giving feedback about the material, also summarizing the material. Hence, they hardly talked in English during the teaching and learning process. Even so, they stimulated to involve actively in the teaching and learning process in the next meetings. The activities had been a checklist in the next meetings such as activity 4, 7 and 
8. But for activity 2, 5, 6, 9 and 10, they finally appeared in the last meeting when they accustomed to be active in the classroom because of the actions in the previous meetings.

Secondly, it was related to observation checklist part B, this observation had a bit the same purpose with part A, but this observation described each students' activity during the teaching and learning process. It might include some activities such students who attend the class, answer questions, pay attention to the material, give feedback, give participation in doing the assignment, take parts in-class activity, concluding the material, and also students who look enthusiast and bother during the teaching and learning process.

XI IPA 1 consisted of 25 students, in all meetings of this cycle, 23 students attended the class because two students got permission for the training of Independence Day ceremony but one of them got permission to join the training in Pinrang Regency for one month and the others were sick. During the teaching and learning process of all meetings, the observation showed that most of the students paid attention but only some of them did not look enthusiast because they had not been able to adjust for new atmosphere after a long holiday. But then, during the actions in this cycle, the frequency of students who look, enthusiast, give feedback, answer questions and give a conclusion about the material increased in every meeting. Moreover, in this cycle, most students actively took parts in each class activity and finished the assignment was given.

\section{Interview}

After implementing the Natural Approach, the researcher carried out a semistructured interview with students of XI IPA 1. This interview consisted of six questions which represent five criterions. The first criterion for item 1 "How is your feeling after learning English by using Natural Approach?" represented students' opinion about learning English by using Natural Approach. Based on the result of the interview, it was found that all students felt happy and fun, they didn't' get bored during teaching and learning process by using the Natural Approach. They had got new knowledge and experiences in teaching English.

The second criterion for item 2 "Is learning English by using Natural Approach encouraged you to produce English?" represented criterion about the influence of using 
Natural Approach in encouraging students to produce English. 24 of 24 Students responded that they were encouraged to produce English so they felt able to use it during teaching and learning process better than before.

Then, the third criterion for item 3 "Are you able to involve actively in teaching and learning process by using Natural Approach?", and item 4 "Is learning English by using Natural Approach encouraged you to interact with fellows or teacher?." Those items talked about the influence of using Natural Approach for students to involve actively during teaching and learning process. For this criterion, all students said that they could involve actively in-class activity and encouraged them to build interaction.

The next criterion for item 5 "Is learning English by using Natural Approach to increase your knowledge about English?" represented the influence of using Natural Approach to increase their knowledge or experiences about English. All students responded that their language store about English had increased which could get new materials about English. The last criterion was item 6 "Do you get difficulties during teaching and learning process by using Natural Approach?" which asked students' obstacles during the actions. There were 10 of 24 students said that they got difficulties to remember the pronunciation of some unfamiliar word.

Next, after the interview section, the researcher and the collaborator conducted the reflection of this cycle. Finally, the last phase was reflection where the researcher and the teacher discussed the conclusion after the action of cycle 1. Based on the result of observation and interview in cycle 1 had been analyzed that students' involvement during teaching and learning process by using Natural Approach had shown good results, but it did not achieve the target percentage yet. Many students were still passive and shy to express ideas through answer questions, give feedback and perform in front of the class. They were not familiarized with classroom interaction using English which still dominated by prominent students during three meetings. Students were still bided by conventional teaching in their first grade. It could be seen from students' difficulties to interact with fellows or teacher.

However, students' activity mostly appeared in the third meeting, but in this case, students were encouraged to be active and involve actively in-class activity for whole 
meetings which targeted more 12 students for activity 2, 3, 4, 5, 6, 8 and 9 each meeting. Based on the interpretation, the researcher and collaborator consequently would conduct the second cycle to create more interactive teaching and learning and decrease students who still passive in this cycle, so students' ability to interact within classroom interaction using English could be improved and better. Both the activities on the actions and materials should be stimulated students' motivation and participation during the teaching and learning process of the next cycle.

Based on the result of analyzing data and reflection on cycle 1 by using the Natural Approach, the actions had been done successfully but it did not achieve the maximal result yet. Students' motivation and involvement in class activity indeed improved, but the accumulation of students who involve actively in the whole meetings was not attained unto target more 12 students for activity 2, 3, 4, 5, 6, 8 and 9 in each meeting. So, the researcher and collaborator decided that it was necessary to conduct the second cycle as a corrective step to get the optimal results. It was begun by the revised plan which the planning phase of this second cycle was implemented into a lesson plan. In this case, the researcher and collaborator modified the previous lesson plan based on the result of the reflecting phase in the first cycle.

The lesson plan which was used still related to Natural Approach. There were no significant differences from the previous lesson plan. However, there were some modifications in the second cycle; that was classroom management, the optimal students' activity during the actions, presenting material and the content of the materials itself. Beside of that, the researcher and collaborator also prepared an observation checklist for noting the classroom activities. The next phase was the action which had been conducted on August $13^{\text {th }}, 15^{\text {th }}$, and $20^{\text {th }} 2018$. In the teaching process, the researcher used three activity phases as well, those are opening, main process, and closing.

Then, the third phase of this cycle was observation which described the results of the study gotten by observation checklist, interview, and questionnaire. 


\section{Observation Checklist}

In the second cycle, generally, the class condition was better than the previous cycle. It could be seen from the result of observation checklists that students were able to involve actively during teaching and learning process. The result of the observation checklist part A showed a higher percentage of each activity. All activities had been fulfilled for each meeting which students who were able to focus and pay attention in teaching and learning process. Moreover, students looked enthusiastic in each meeting which had an effect on their performance to involve actively in-class activity.

They kept their participation to ask a question or give answer and feedback which dominated by using English actively. Automatically, it proved that they had been familiarized with classroom interaction. Hence, it led to a good result in which students' interaction ability within classroom interaction was improved. The same cases also appeared in the result of observation checklist B.

The result showed the physical classroom activity had had good progress for all activities of this cycle. For each meeting, the accumulations of students who pay attention

reach $100 \%$ which equal with students who pay attention during teaching and learning process. All students focused on the explanation and follow the instructions so they could be easier to involve actively in the classroom activity.

Many students were encouraged actively to take parts in-class activity and give feedback or responses to the explanation and answer questions because they felt enthusiastic. Moreover, most of the students tried to be conspicuous in the teaching and learning process, they were stimulated to produce English and give a conclusion about the material. In this cycle, activity 2, 3, 4, 5, 6, 8 and 9 had achieved the target which more 12 students in each meeting.

\section{Interview}

The interview was conducted after the last meeting of this cycle. The five criterions of the guided interview were represented by six questions. In this cycle, the respondents were 25 students. Item 1 as the first criterion contained question about students' feeling 
after conducting English teaching by using the Natural Approach. All of them claimed that teaching English by using Natural Approach could make them happy and felt fun during teaching and learning process. They got many knowledge and new learning system that never been given by their teacher.

The next criterion for item 2 asked about the influence of using Natural Approach to encourage students to produce English. 25 students responded that they were able to produce English because the class activities had been encouraged them to use English within classroom interaction. Then, for item 3 and 4 which both of them represented the third criterion was about the influence of using Natural Approach for encouraging students to involve actively in giving participation. 25 students replied that they got encouragement to be active in giving participation so they were able to create interaction with fellows or teacher in-class activity.

Item 5 represented the fourth criterion which talked about the influence of the using Natural Approach to increase their knowledge or experiences about English. All students claimed that they got new vocabularies and experiences for new English learning atmosphere. It had directed them to know more about English than before.

The last item which represented also the last criterion in this interview asked about students' obstacles or problems during teaching and learning process. For this last item, 4 students honestly claimed that still difficult to pronounce some words correctly, although they had been guided to solve the problems in the teaching and learning process.

\section{Questionnaire}

The questionnaire was used to support the primary data after the researcher and collaborator considered a good result from this cycle. The researcher gave 10 items to be answered by 25 students. This questionnaire supplied alternative answers "yes" and "no" options.

Item number 1 asked students' opinion whether the learning English by using Natural Approach was interesting and impressive for them or not. The whole students answered "yes" which showed that students interested and got impressive in learning English by using the Natural Approach. Question about whether students focused to learn 
English during the teaching and learning process or not was item 2. For this item also, 25 students answered "yes". Based on the answer, it was clear that students felt enjoy in the teaching and learning process.

Next question was item 3 which asked students' opinion whether they were easier to understand about English by using Natural Approach. The whole students chose the answer "yes". Their answers showed the success of the presenting materials to students and their ability to catch the materials easily. For item 4 asked about whether the using Natural Approach could encourage students to participateintheactively in-class activity. 25 students answered this item with "yes", so it was clear that the using Natural Approach could improve students' ability to involve in teaching and learning process. Item 5 asked whether the Natural Approach motivated students to do assignments or exercises. This item was answered "yes" by the whole students. It meant that using Natural Approach motivated students to learn.

Next item was questioned about whether students were active to express their ideas by using the Natural Approach in learning English. For this item, there were 20 students answered "yes", meanwhile, 5 students answered "no". Based on their answer, it was clear that the majority of students got the benefits of using Natural Approach to be active in expressing their ideas in teaching and learning process. Item 7 asked whether the user of the Natural Approach improved students' ability to interact with each other by using English. There are 24 students answered "yes" and only 1 student answered "no". It was obvious that the learning English by using Natural Approach to improve and stimulate students in order to build interaction within the classroom.

Both item 8 and 9 concerned about whether the user of Natural Approach stimulated students to be active in giving responses to the materials were given. Item 8 asked students' responses to ask the question which 24 students answered "yes" and 1 student answered "no". And for item 9 which asked students' responses to answer questions, the whole students claimed it by answering "yes". It proved that students were active to give responses during teaching and learning process by using the Natural Approach.The last item asked whether students got any obstacles or difficulties during teaching and learning process by using the Natural Approach. There are 4 students answered "yes" and 21 
students answered "no" for this item. Based on the answers, the majority of students felt enjoy to learn English by using the Natural Approach.

Finally, the last phase of this cycle was reflection which carried out after analyzing the result of the observation checklist, interview, and questionnaire. In this cycle, the goal of the lesson was achieved. The researcher and collaborator felt satisfied because the implementation of the actions was done very well and students had a significant improvement for their interaction ability. The classroom atmosphere was more alive because students were encouraged to involve active and stimulated to give participation or responses during the teaching and learning process.

It was indicated by the results of target achievement in an observation checklist, the results of the interview and questionnaire. Therefore, the researcher and collaborator decided to stop the cycle of Classroom Action Research because it had already succeeded.

Based on the explanation above, it could be assumed that the implementing Classroom Action Research in improving students' interaction ability by using the Natural Approach was appropriate with the planning that had been discussed. Every action was planned as good as possible so that the teaching and learning activities could be accomplished well.

\section{B. Discussion}

This study deals the effectiveness of using Natural Approach to improve students' interaction ability at second grade of SMAN 4 Pinrang. The results of the research proved that the Natural Approach was effective to improve students' interaction ability. Students had significant improvement after conducting the actions in two cycles. The use of Natural Approach was implemented in three meetings of each cycle. The actions were conducted in three stages that were comprehension (pre-production), early production and speech emergence. For one stage was conducted in one meeting, hence, the action was in three meetings of each cycle.

Those stages stimulated students to be active as well they were encouraged to involve their mind and gesture actively to do the whole classroom activities of each stage. It will aim them to familiarize with classroom interaction to avoid a passive teaching and 
learning process. Natural Approach helped students to learn how to produce English communicatively through interaction within the classroom.

The discussion above was described the role of the class activities which set in three stages. Those activities had brought up the progress of students' improvement in English teaching and learning process. It showed that students who passive during teaching and learning process were decreased after the implementation of the actions. The percentage of Activity 2 till Activity 7 from cycle 1 to cycle 2 increased significantly. Activity 2 which described students who pay attention during teaching and learning process had increased from $86.95 \%$ to $100 \%$. Then, activity 3 which described students who take parts in-class activity increased from $63.76 \%$ to $93.79 \%$. Next for activity 4 about students who give feedback showed the increasing from $39.12 \%$ to $68.94 \%$. Activity 5 also had increased from $40.57 \%$ to $80.34 \%$. Students who look enthusiastic during the actions had increased in cycle 2 which from $55.06 \%$ to $86.43 \%$. For the next activity which students who give a conclusion about the material also increased from $37.67 \%$ to $58.75 \%$. And other results for activity 7 , it was about students who bother during teaching and learning process which had decreased from $7.24 \%$ to $4.76 \%$.

The result of students' interviews in XI IPA 1 in cycle 1 and 2 showed that many students felt more encouraged to interact with fellows or teacher within classroom interaction by using English. They claimed that they were more able to involve actively in giving participation during teaching and learning process. Students got the ability after the using of Natural Approach in English class activity. Students also confessed that they felt fun and happy, also found new knowledge and experiences during the actions.

The results of the questionnaire also described that students were interested to learn English and encouraged to focus on teaching and learning process by using the Natural Approach. They were able to understand the material easily and give participation or doing assignments actively. Moreover, most of them were stimulated to involve actively in the teaching and learning process. Those descriptions indicated students' interaction ability by using the Natural Approach was improved. 


\section{Conclusions}

The results described that students were more active to interact with fellows or teacher by using English so interactive teaching and learning process was built. They could participate in performing instructions and conveying responses during teaching and learning process. They were active and enthusiastic in giving feedback, answering questions, moreover, doing interaction within classroom activity. They were able to build interaction in order to communicate the language. Hence, interactive and communicative teaching and learning could be created. Those results indicated that the using of Natural Approach in learning English was effective to improve students' interaction ability at second grade of SMAN 4 Pinrang.

Furthermore, students were also motivated to learn English and encouraged to focus on teaching and learning process by using the Natural Approach. They were able to understand the material easily and give participation or doing assignments actively. Every class activity of each Comprehension (Pre-production), Early Production, and Speech Emergence stage in the two cycles encouraged them to involve actively in the teaching and learning process. Those activities had brought up the progress of students' improvement in English teaching and learning process. It showed that students who passive during teaching and learning process were decreased after the implementation of the actions.

\section{Suggestions}

Regarding this research, the writer would like to propose a suggestion. Firstly for the teachers, they should choose some creative ways to make students more motivated, communicative, and active in joining the lesson. It is important for the teacher to create an enjoyable atmosphere and familiarization to the interaction within the classroom of the teaching-learning processing order to make students eager to improve their English.

Secondly, for students, they should take benefits from the implementation of the Natural Approach to improve their English proficiency. Besides, they should courage themselves to be an active learner in the classroom, to discover what they do not know, and learn as much as possible. 
Inspiring: English Education Journal

Volume I No 2September2018

\section{References}

Bahar, A. Kaharuddin. 2014. Interactional Speaking. Yogyakarta: Trustmedia Publishing.

Brown, H. Douglas. 2001. Teaching by Principle: An Interactive Approach to Language Pedagogy. New York: Pearson Education.

Emzir. 2011. MetodePenelitianKualitatif: Analisis Data. Jakarta: Rajawali Press.

Herdiansyah, Haris. 2013. Wawncara, Observasi, dan Focus Groups: SebagaiInstrumenPenggalian Data Kualitatif. Jakarta: Rajawali Press.

Narbuko, Cholid\& Abu Achmadi. 2010. MetodologiPenelitian. Jakarta: PT. BumiAksara.

Ray, L. G. 1981. Educational Research: Competencies for Analysis \& Application, (Ohio: Charles E. Merrill Publishing Co.).

Richards, Jack C., and Theodore S. Rodgers. 1995. Approaches and Methods in Language Teaching. New York: Cambridge University Press.

Sapir, Edward. 1949. Language: An Introduction to the Study of Speech. New York: Harcourt, Brace \& World, Inc.

Thomas, Ann Malamah. 1988. Classroom Interaction. New York: Oxford University Press.

Yaumi, Muhammad \&MuljonoDamopolii. 2014. Action Research (Teori, Model, danAplikasi). Jakarta: Kencana, Prenadamedia Group. 